\title{
The 100\% Reserve Reform: Calamity or Opportunity?
}

\author{
Christian Pfister ${ }^{1}$
}

\author{
November 2020, WP \#786
}

\begin{abstract}
This paper considers the various 100\% Reserve plans that have appeared since the interwar period and have since then been adapted. In all formulations of those schemes, Government liabilities (cash, central bank reserves and short-term Treasuries) back banks' sight deposits. This organization contrasts with current so-called "fractional reserve banking", in which, as a result of reserve requirements imposed by the central bank (Drumetz et al., 2015), reserves back only a small fraction of sight deposits. The paper briefly presents the six categories of plans. It then highlights their common features as well as their differences, showing that the differences are more numerous than the common features. The criticisms voiced against the different formulations of $100 \%$ Reserves are exposed, adding those of the author and distinguishing between the doubts expressed on the validity of the analysis on one hand, and some undesirable consequences of the reform on the other. In spite of these criticisms, it then shown that the $100 \%$ Reserve reform is becoming topical, with recent private sector, central banks and political initiatives that relate to it. Overall, the 100\% Reserve reform does not appear as a meaningful opportunity to improve the functioning of banking systems. Furthermore, at least one of its variants could easily turn into a calamity. Fortunately, it is not that variant that is getting more topical.
\end{abstract}

Keywords: 100\% Reserve, Chicago Plan, deposited currency, full-reserve, limited purpose banking, narrow banking, sovereign money

JEL classification: E42, E51, E52, E58

\footnotetext{
${ }^{1}$ Banque de France, Banque de France, Paris 1 Panthéon Sorbonne and Sciences Po. I would like to thank Françoise Drumetz and Nicolas de Sèze, as well as an anonymous referee, for their remarks and remain solely responsible for any error.
}

The views expressed are mine and do not necessarily reflect those of the Banque de France, the Eurosystem, Paris 1 Panthéon Sorbonne or Sciences Po. This document is available on publications.banque-france.fr/en 


\section{NON-TECHNICAL SUMMARY}

100\% Reserve - also called Full-Reserve - plans have appeared in the interwar period and have since then been adapted, in response either to critiques or to changing circumstances. In all formulations of those schemes, Government liabilities (cash, central bank reserves and short-term Treasuries) back banks' sight deposits or at least some of them. This is in contrast with current "fractional reserve banking" in which reserves back only a small fraction of sight deposits.

Among the various plans, one can distinguish six main streams. The Chicago Plan (CP) appeared first, in the wake of the Great Depression. Tobin's proposal for a Deposited Currency (DC) followed much later, in the context of the U.S. savings banks' debacle. Narrow Banking (NB) was first contemporaneous of Tobin's proposal but was subsequently adapted on the back of the Global Financial Crisis (GFC). Limited Purpose Banking (LPB) was developed in the first ten years of this century, in an environment of financial innovation and rapidly expanding financial markets. The most recent proposals, the plan put forward by Benes and Kumhof (2012) (B\&K) and Sovereign Money (SM) are based on the premise that the GFC resulted from an allocation of credit to "unproductive" uses.

The common motivations of 100\% Reserve plans are twofold: make narrow money more controllable (except for LPB); and reduce moral hazard related to the government's implicit support of banks (especially for LPB). However, there are many differences in the various plans, as shown in the table below.

Table: Differences in 100\% Reserve plans

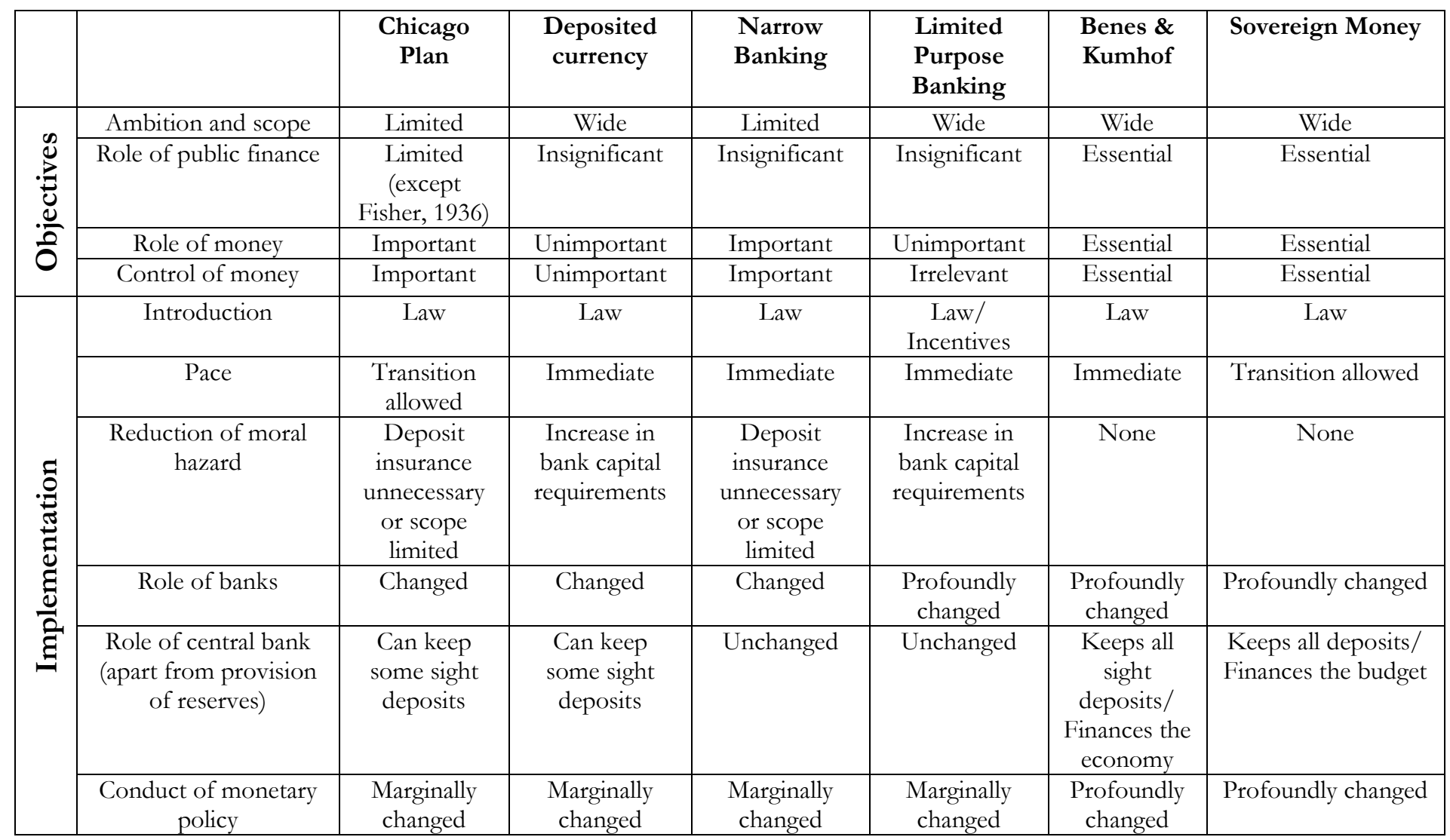

Overall, several features make B\&K and SM distinct from other plans: the wide ambition and broad scope of the reform, the role of public finance considerations in motivating the reform and the one of the Government in implementing it, the tight control on the creation of money and the 
allocation of credit. In comparison, LPB appears as a "radicalization" of the CP and NB. Finally, DC is original to the extent that it is "à la carte".

$100 \%$ Reserve has been criticized by academics from the beginning, including in its own camp. Technical limits relate to the substitutability between sight deposits and other assets, to transition issues, to the difficulty to control money, and in SM to the need to have a correct model of the economy. Criticisms that are more fundamental consider 100\% Reserve as too narrow an approach, static, and supporting excessive claims. In particular, LPB over-emphasizes the capacities of financial markets and fund managers, whereas SM has recourse to a notion of "debt-free payment" that has been denounced as an "illusion". Furthermore, the implementation of some $100 \%$ Reserve plans would have consequences that cast doubts on the merits of the whole project. Notably, in SM, monetary policy would risk becoming a compartment of fiscal and industrial policies, and moral hazard would not be eliminated by B\&K or SM, as the Government (in B\&K) or the central bank (in SM) would play a major role in allocating credit and would thus be held directly responsible for ensuring financial stability.

In spite of the criticisms it has raised, $100 \%$ Reserve could get more topical in the coming years because of private sector, central bank, and political initiatives. In particular, the issuance of global stablecoins by the private sector or of central bank digital currencies by central banks could lead to a loss of resources by banks, as would be the case with $100 \%$ Reserve. Fortunately, these projects are reminiscent of DC, the one among 100\% Reserve plans least susceptible of upsetting banking intermediation.

\title{
La Réforme du 100\% Réserves : Opportunité ou Calamité ?
}

\author{
RÉSUMÉ
}

Ce papier se penche sur les différents plans de 100\% réserves qui sont apparus depuis l'entre-deux guerres et ont depuis été adaptés. Dans toutes les formulations de ces dispositifs, des éléments de passif émis par les autorités publiques (monnaie fiduciaire, réserves de banque centrale ou bons du Trésor à court terme) viennent en adossement des dépôts à vue dans les banques ou au moins d'une partie d'entre eux. Cette organisation s'oppose au système actuel de "réserves fractionnaires" où les dépôts à vue ne sont adossés à des réserves que pour une modeste fraction, en conséquence de la réglementation des réserves obligatoires édictée par la banque centrale. Le papier présente brièvement les six différentes catégories de plans. Il met ensuite en lumière leurs points communs ainsi que leurs différences et montre que les deuxièmes sont plus nombreuses que les premiers. Les critiques adressées aux diverses formulations du 100\% réserves sont exposées, en y ajoutant celles de l'auteur et en distinguant entre doutes exprimés sur la validité de l'analyse d'une part, certaines conséquences indésirables de la réforme d'autre part. En dépit de ces critiques, il est ensuite montré que la réforme du 100\% réserves gagne en actualité, des initiatives récentes de la part du secteur privé, des banques centrales ou d'acteurs politiques pouvant lui être rattachées. Dans l'ensemble, le 100\% réserves ne ressort pas comme une opportunité significative pour améliorer le fonctionnement des systèmes bancaires. En outre, au moins une de ses variantes pourrait facilement se transformer en calamité. Heureusement, ce n'est pas celle qui est la plus actuelle.

Les Documents de travail reflètent les idées personnelles de leurs auteurs et n'expriment pas nécessairement la position de la Banque de France. Ils sont disponibles sur publications.banque-france.fr 


\section{Introduction}

100\% Reserve - also called Full-Reserve - plans have appeared in the interwar period and have since then been adapted, in response either to criticisms or to changing circumstances. In all formulations of those schemes, Government liabilities (cash, central bank reserves and short-term Treasuries) back banks' sight deposits or at least some of them. This is in contrast with current socalled "fractional reserve banking" in which, as a result of reserve requirements imposed by the central bank (Drumetz et al., 2015), reserves back only a small fraction of sight deposits.

The first part of the paper briefly presents the various plans that have emerged. The second part highlights their common features as well as their differences. The third part exposes the numerous criticisms voiced against its different formulations. The fourth part shows that the $100 \%$ Reserve reform is becoming topical, with recent private sector, central banks and political initiatives that relate to it. The fifth part concludes.

\section{Various plans}

Leaving aside the distant filiation with the Currency School (Lainà, 2015), various plans have been put forward since the Great Depression. In chronological order of appearance, one can distinguish six main streams (in each case, I give the references that I deem most significant and that I will use in the following to characterize these streams). The Chicago Plan, hereafter the CP (Knight et al., 1933; Fisher, 1936; Friedman, 1965) appeared first. Tobin's proposal for a Deposited Currency, hereafter DC (Tobin, 1985, 1987) followed much later. Narrow Banking, hereafter NB (Litan, 1987; Phillips, 1995; Kay, 2009) was first contemporaneous of Tobin's proposal but was subsequently adapted. Limited Purpose Banking, hereafter LPB (Kotlikoff, 2010; Chamley et al., 2012; Cochrane, 2014) was developed in this century. The plan put forward by Benes and Kumhof (2012), hereafter B\&K and Sovereign Money, hereafter SM (Jackson and Dyson, 2012; Dyson et al., 2016), are the most recent proposals, although Soddy (1926) is often considered as a precursor of SM.

- The CP was elaborated in the wake of the Great Depression. It is based on a monetarist diagnosis of the crisis. As a result of too low a supply of liquidity by the Federal Reserve (Fed), the banks facing deposit withdrawals (bank runs) would have restrained their supply of credit, depriving the economy of the means of payment necessary to its good functioning and thus accentuating the recession. Consequently, the supporters of $\mathrm{CP}$ propose to dissociate the distribution of credit and the provision of means of payment by indirectly assigning the latter to the central bank. All sight deposits with commercial banks would be backed by equal amount of reserves held with the central bank. It would also be possible to open sight deposit accounts with the central bank or the Post Office. In that way, any bank run would become groundless. Provided of course that the banks hold appropriate collateral to get refinancing from the central bank, the supply of reserves corresponding to the demand for money as a means of transactions would become endogenous, just as the central bank refinances the demand for reserves resulting from the use of currency by the public. The factor that the promoters of CP consider as responsible of the Great Depression, and more generally of economic crises, would thus be eliminated.

- DC, just as NB (see below), was elaborated from the mid-1980s in the context of the crisis of U.S. savings banks. The deregulation of the savings banks industry, up to then very protected and heavily regulated, with close links with local government, had not been matched with a corresponding responsibility of the actors. This had lead them to distribute 
far too much credit in order to increase their market share, especially in the mortgage market. The recession of the early 1980s, resulting notably from the second oil price shock, lead to the savings banks' debacle, prompting the Congress to recapitalize the savings banks at great cost for the taxpayers. The objective of DC is thus to reduce moral hazard, and more precisely the excessive risk-taking of banks with the implicit backing of government. Although it gives its name to the plan, the backing of sight deposits with reserves does not play a major role in Tobin $(1985,1987)$. It would be left to the choice of the public, with the banks proposing or not to offer depositors backed sight deposits. As in the $\mathrm{CP}$, the public could also hold sight deposits with the central bank or the Post Office.

- NB appears in the same context as DC. As on DC, the main objective of the reform is to limit moral hazard. However, the backing of sight deposits with reserves would play an important role in the case of NB. It would be mandatory and go along with the suppression or the reduction of the coverage of deposit insurance.

- LPB takes up the objective of limiting of moral hazard but is also developed in the context of rapid financial innovation and growth of financial markets, especially the one of securitization, in the first decade of the 2000s. The possibilities opened by technological progress, making all financial assets potentially liquid, would allow using them in transactions as substitutes for low-yielding sight deposits, notably in the form of shares of mutual funds.

- B\&K relate their analysis to the CP. However, it is possible to see it as closer to SM (see below). Their approach is based on the idea that the GFC was caused by the distribution of credit to "unproductive" uses. To remedy this problem and allow the authorities to control the money stock, the creation of reserves would only benefit the Treasury, by crediting its account with the central bank. The Treasury would use the reserves to distribute credit to the uses considered as "productive", to smooth the economic cycle. All transactions would be settled using accounts with the central bank.

- Finally, SM is based on a diagnosis the crisis similar to the one in Benes and Kumhof (2012). However, the plan differs from B\&K in two features. Firstly, the reserves created for the Treasury, instead of financing credit to the economy, would be part of government revenue and thus finance the budget. More precisely, the Treasury would use these funds to smooth the economic cycle, by either paying lump sum benefits to households ("helicopter money"), or financing other expenditure and reducing taxes. Secondly, the central bank could also distribute credit to banks, with the banks redistributing them to the economy, as a complement to the money created as government revenue.

\section{Common features but also differences}

\subsection{Common features}

There are some common motivations and proposals for the organization of the financial system.

The common motivations are twofold:

- Make narrow money (i.e. M1, the sum of cash and sight deposits held by non-bank residents) more controllable (except for LPB);

- Reduce moral hazard related to the government's implicit support of banks (especially for LPB). 
Overall, the objective is to make the economy more stable and to achieve this goal at a socially acceptable cost (i.e. at a lower cost than at the time the plan is exposed).

The organization of the financial system that is envisaged rests on two features:

- The separation of payment services and financing of the economy. In most cases, this would be achieved either by splitting banks' balance sheets, with different assets backing sight deposits and other banks' liabilities (Knight et al., 1933; Fisher, 1936; DC), or by splitting banks themselves (Friedman, 1965; Phillips, 1995; B\&K; SM). One exception is $\mathrm{LPB}$, in which banks as they currently operate would disappear altogether, with cash or shares of money market funds investing in short-term Treasuries used for payments and with other types of mutual funds financing the economy.

- In parallel (except for LPB), central bank money is given an enhanced role in the conduct of transactions either because sight deposits would be held with the central bank (B\&K; $\mathrm{SM}$ ) or because it would back entirely sight deposits (other proposals except DC) or at least some of them (DC).

\subsection{Differences}

There are differences both in the objectives that are pursued and in the implementation of the reform (see Table below).

Table: Differences in 100\% Reserve plans

\begin{tabular}{|c|c|c|c|c|c|c|c|}
\hline & & Chicago Plan & $\begin{array}{l}\text { Deposited } \\
\text { currency }\end{array}$ & $\begin{array}{l}\text { Narrow } \\
\text { Banking }\end{array}$ & $\begin{array}{l}\text { Limited } \\
\text { Purpose } \\
\text { Banking }\end{array}$ & $\begin{array}{l}\text { Benes \& } \\
\text { Kumhof }\end{array}$ & $\begin{array}{l}\text { Sovereign } \\
\text { Money }\end{array}$ \\
\hline \multirow{3}{*}{$\cdot \frac{\stackrel{D}{u}^{\infty}}{\frac{u}{2}}$} & Ambition and scope & Limited & Wide & Limited & Wide & Wide & Wide \\
\hline & Role of public finance & $\begin{array}{l}\text { Limited (except Fisher, } \\
\text { 1936) }\end{array}$ & Insignificant & Insignificant & Insignificant & Essential & Essential \\
\hline & Control of money & Important & Unimportant & Important & Irrelevant & Essential & Essential \\
\hline \multirow{5}{*}{ 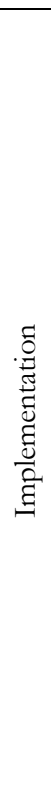 } & Introduction & Law & Law & Law & $\begin{array}{l}\text { Law/Incentive } \\
\mathrm{s}\end{array}$ & Law & Law \\
\hline & Pace & Transition allowed & Immediate & Immediate & Immediate & Immediate & $\begin{array}{l}\text { Transition } \\
\text { allowed }\end{array}$ \\
\hline & Role of banks & Changed & Changed & Changed & $\begin{array}{l}\text { Profoundly } \\
\text { changed }\end{array}$ & $\begin{array}{l}\text { Profoundly } \\
\text { changed }\end{array}$ & $\begin{array}{l}\text { Profoundly } \\
\text { changed }\end{array}$ \\
\hline & $\begin{array}{l}\text { Role of central bank } \\
\text { (apart from provision of } \\
\text { reserves) }\end{array}$ & $\begin{array}{l}\text { Can keep some sight } \\
\text { deposits }\end{array}$ & $\begin{array}{l}\text { Can keep some } \\
\text { sight deposits }\end{array}$ & Unchanged & Unchanged & $\begin{array}{l}\text { Keeps all sight } \\
\text { deposits/Fina } \\
\text { nces the } \\
\text { economy }\end{array}$ & $\begin{array}{l}\text { Keeps all } \\
\text { deposits/Financ } \\
\text { es the budget }\end{array}$ \\
\hline & $\begin{array}{l}\text { Conduct of monetary } \\
\text { policy }\end{array}$ & Marginally changed & $\begin{array}{l}\text { Marginally } \\
\text { changed }\end{array}$ & $\begin{array}{l}\text { Marginally } \\
\text { changed }\end{array}$ & $\begin{array}{l}\text { Marginally } \\
\text { changed }\end{array}$ & $\begin{array}{l}\text { Profoundly } \\
\text { changed }\end{array}$ & $\begin{array}{l}\text { Profoundly } \\
\text { changed }\end{array}$ \\
\hline
\end{tabular}


Regarding the objectives, the differences relate to the ambition and scope of the reform, the role of public finance considerations in promoting it, the role assigned to money, and relatedly the need to control it.

- The ambition and scope of the reform are limited in the cases of the CP and NB (except for Kay, 2009), with the reform applying to banks and no new constraints put either on their collection of liabilities other than sight deposits, or on their lending activities. In other proposals, $100 \%$ Reserve is part of a broader reform. This is the case in Tobin (1987), who proposes to subject banks' asset portfolios to regulations and to increase their capital requirements, and in Kay (2009), who also suggests restricting banks' activities to limit their risk-taking. This is the case as well for LPB, in which banks are replaced by mutual funds, an evolution that is close to what Friedman (1965) had envisaged for non-payment activities of banks, as banks "would be sliced off into other branches operating like small-scale investment trusts". Finally, this is true in B\&K and SM, in which the reform extends to the distribution of credit.

- In Friedman (1965), NB, DC and LPB, improving the state of public finance plays no significant role in promoting the reform. One exception in CP is Fisher (1936): even though his main objective is to avoid banks restraining the supply of money through the distribution of credit in times of crises, the re-appropriation of the seigniorage captured by banks in doing so is also one of the objectives he puts forward. This would be achieved through the full backing of sight deposits by unremunerated central bank reserves, whereas Friedman (1965) and DC suggest that reserves held by 100\% Reserve banks should be remunerated, so that they do not have to rely solely on payment services fees as an income. Conversely, the role of public finance considerations is essential in B\&K and SM. In these plans, there would be a front-loading of seigniorage, with created reserves credited to the account of the Treasury at the central bank (entirely in B\&K, the bulk of them in SM).

- At one extreme, LPB views money's role as a means of transaction or store of value as essentially obsolete, as it can be replaced with yield-serving assets such as mutual funds shares. To paraphrase Keynes (1923) referring to the gold standard, it is a "barbarous relic". More traditionally, the $\mathrm{CP}, \mathrm{NB}$ and DC envisage money as an instrument put at the disposal of economic agents, and managed by the government (more specifically the central bank), in order to maximize social welfare. As Fisher (1936) puts it, the purpose of $100 \%$ Reserve - or " $100 \%$ Money" as he calls it - is to "Nationalize money but (...) not nationalize banking". In contrast, B\&K and SM can be considered as followers of Knapp (1905), in that they view money as an attribute of government. At the heart of their approaches is the notion of "debt-free" money (i.e. money that does not have to be backed because it is nonredeemable and unremunerated).

- Consequently, controlling money is irrelevant for LBP. It is also of little relevance for DC, for similar reasons relating to financial innovation that broadens the scope of assets that can act as substitutes to sight deposits. In the more "monetarist" camp of the CP and NB, "money matters", but it should only be controlled indirectly, through the supply of central bank reserves. In B\&K and SM, the control of money is essential, so that the government should nip in the bud its creation for "unproductive uses", and thus control credit.

Regarding the implementation of the reform, there are differences in the ways to introduce it, its pace of introduction, means used to reduce moral hazard in banking activities, the roles of banks and the central bank, and the conduct of monetary policy. 
- In most plans, law would impose the reform. Two exceptions are DC and Cochrane's (2014) proposal in support of LPB. In effect, DC would be allowed but not imposed: some financial institutions could choose to operate as 100\% Reserve banks (or the central bank or the Post Office could open accounts to the public) and depositors could choose to deposit or not with them. Cochrane (2014) proposes to create incentives for banks to strongly increase their levels of equity (up, ideally, to 100\% of their assets) by taxing what he labels as "run-prone contracts" (i.e. contracts that "promise fixed values and first-comefirst-served payments", thus sight deposits in the first place). This proposal of a Pigouvian tax echoes Tobin's suggestion to tax short-term capital flows in order to preserve the autonomy of monetary policies in the context of a fixed exchange rate system (Tobin, 1978).

- Also in most plans, the reform would be immediate. However, in some plans (CP, SM) a transition would be allowed, in order to avoid disrupting the financial system.

- In the CP and NB, moral hazard would be reduced by making deposit insurance unnecessary or limiting its scope, thus lowering the incentives of banks to take risks. In the same vein, Friedman (1965) also proposes to eliminate controls on individual banks, since the regulator or supervisor would be reluctant to admit that she has done a poor job, and thus would practice regulatory forbearance rather than sanction a bank in poor financial health. Finally, increasing the level of equity of banks eliminates a source of moral hazard in DC and LPB, whereas moral hazard is not considered in B\&K and SM.

- In 100\% Reserve plans, the role of banks could be changed in two regards: in keeping accounts or in financing the economy. However, this would not be the case in CP or DC, or else marginally - to the extent that accounts could be opened with the central bank or the Post Office, implying a certain degree of bank disintermediation. In contrast, the role of banks in collecting deposits would be profoundly changed in B\&K, with all payments accounts kept in the central bank, as well as in SM, with not only payment accounts (labelled "Transaction Accounts") but also saving accounts (labelled "Investment Accounts") kept in the central bank and "Investment Accounts" mirrored in the liabilities of the banks. In the latter plans, the role of banks in financing the economy would also change drastically: in $\mathrm{B} \& \mathrm{~K}$, this would be because the Treasury would distribute credit; in SM, this would be because the bulk of the reserves would be created as government revenue. Finally, in LPB, banks as they currently operate would disappear either formally or, in Cochrane (2014), because they are deleveraged.

- In all 100\% Reserve plans, the central bank either would provide cash and reserves backing sight deposits or directly keep them. In some plans (Friedman, 1965; DC; LPB), short-term Treasuries could also be held as assets backing sight deposits (or mutual funds shares in LPB). As mentioned above, the central bank could also keep some sight deposits in the CP and DC. More importantly, the central bank would finance the economy through the Treasury's account in B\&K, and the budget in SM. In the latter case, at least formally (see third part), the central bank would also decide on the amount of reserves to be created, based on its economic forecasts (Dyson et al., 2016). Additionally, in case the funding provided by Investment Accounts would not be deemed "sufficient", the central bank could make up for the shortfall by creating more reserves and lending them to commercial banks.

- The conduct of monetary policy would be basically unchanged in the CP, NB, LPB and DC, except that the central bank would provide reserves to accommodate the aggregate banks' demand to back sight deposits (or money market mutual funds shares in LPB), as it 
currently does to accommodate the demand for banknotes. Conversely, in B\&K and SM, it would undergo two deep modifications. First, the objective of monetary policy would be amended, explicitly by adding an objective of financing only the "productive economy", and implicitly by leading the central bank to have an intermediary objective on money, as in monetary targeting, because of the importance attached in these plans to the control of money. Secondly, the implementation of monetary policy would change profoundly. In $\mathrm{B} \& \mathrm{~K}$, the creation of reserves would allow controlling money, whereas the distribution of credit by the Treasury would allow controlling credit; furthermore, there would be a policy rate. In SM, monetary policy works by financing public expenditure and there would be no policy rate. However, the central bank could control the cost of credit by setting the interest rate at which it would indirectly finance business lending by banks, with the mechanism described above, and providing whatever quantity is demanded. SM does not consider the opposite possibility, in which the cost of credit would be viewed as too low, although in principle the central bank could withdraw liquidity by borrowing from banks.

Overall, it appears that, among 100\% Reserve plans, there are many more differences than common features. Furthermore, several features make B\&K and SM distinct from other plans: the wide ambition and broad scope of the reform, the role of public finance considerations in motivating the reform and the one of the Government in implementing it, the tight control on the creation of money and the allocation of credit. In comparison, LPB can be seen as a "radicalization" of the CP and NB, with some of its features anticipated by Friedman (1965). Finally, DC is original to the extent that it is "à la carte", although it draws heavily on the CP.

\section{A reform which is criticized}

$100 \%$ Reserve has been criticized by academics from the beginning, including in its own camp (see e.g. Hart, 1935, and Tobin, 1963) ${ }^{1}$. Some of these criticisms have led to alterations of the original framework, notably with a shift of emphasis from money control, characteristic of the $\mathrm{CP}$, to financial stability and moral hazard considerations, put forward in NB and LPB, whereas SM shifts the emphasis back to the creation of money, extending it to the allocation of credit. This third part of the paper sums up these criticisms and add my own, distinguishing between the doubts expressed on the validity of the analysis on one hand, and some undesirable consequences of plans on the other.

\subsection{An analysis that is subject to limits}

Critiques have underlined technical but also more fundamental limits.

Many technical limits were signaled as early as the first formulations of the CP. They relate to the substitutability between sight deposits and other assets, to transition issues, to the difficulty to control money, and in SM to the need to have a correct model of the economy.

- The possibility for economic agents to substitute the use of quasi-money for sight deposits in the settlement of transactions, and the willingness of banks to accommodate this substitution, was mentioned for instance by Hart (1935), one of the signatories of the initial CP (Knight et al., 1933). In fact, this is a serious impediment for the CP, which insists on a specific role for narrow money, the insufficient supply of which is viewed in that plan as

\footnotetext{
${ }^{1}$ In the framework of the Swiss popular vote on SM (« Monnaie pleine » or « Vollgeld ) on 10 June 2018, there were also statements by politicians and central bankers (see e.g. Jordan, 2018).
} 
responsible for the severity of the Great Depression. However, as pointed by Allen (1993), this only matters to the extent that the diagnosis is correct (see below).

- Hart (1935) mentions transition issues of three sorts. Firstly, there would be uncertainty about the effects of the reform, as the transition would probably induce fluctuations in the demand for money, deemed important for the stability of the economy. Secondly, there could be disruptions in financial markets, where banks play an important role. Thirdly, there could be a problem of financial stability as the new institutions that would replace traditional banks in the financing of the economy would become more fragile and susceptible to runs, since they would lose access to a cheap source of funds, i.e. sight deposits (in fact, this is a more permanent issue).

- Difficulties to control money have been evidenced by the rather poor performance of monetary targeting in the 1970-1980 period, even though those central banks that practiced it, as the Deutsche Bundesbank, managed to tame inflationary pressure more successfully than the others did (Drumetz et al., 2015). Indeed, the quantity of money is influenced not only when credit is distributed by banks but also by bank loan repayments, anticipated or not, by portfolio shifts between securities and deposits by banks versus other institutions, as well as between residents and non-residents, which are all factors extremely difficult to forecast.

- In that regard, there would be a need to have a correct model of the economy, as acknowledged by Dow et al. (2015). Even more demanding, money (for the CP, NB) or money and credit (for SM) would have to play a significant role in that model, and echoing the transition issue mentioned by Hart (1935), as he anticipated on the "Lucas critique" (Lucas, 1976), the relations exhibited in the model would have to hold in the post-reform economy.

Most of the fundamental limits have been pointed in the more recent past. According to these criticisms, $100 \%$ Reserve is too narrow an approach, static, and supporting excessive claims.

- Even in their broader versions, 100\% Reserve plans often offer too narrow an approach because other policy measures are usually not taken into account or, when it is the case, their efficacy is denied too readily. This is the case for fiscal policy as a tool for macroeconomic stabilization (and in some cases destabilization), for prudential (including macroprudential) policies, and for structural (tax, housing, competition...) policies. Deposit insurance is a case in point: its suppression would help reduce moral hazard, but since its adoption, runs very seldom occur at the counter of banks, but rather in the money market (Gorton, 2009; Bacchetta, 2018). However, the interbank market would exist under any of the reforms proposed, even though its access could be limited to narrow banks (Phillips, 1995; Kay, 2009). This narrow approach culminates in "monetary mysticism" (i.e. over-stating the role of money), particularly in the CP and SM. In fact, as pointed by Tobin (1963), banks do not have access to "fountain pen money" that would be available ad libitum. There are liquidity limits to their capacity to create money, as the money created when the credit is granted moves most often to other banks when the funds are spent. There are also profitability limits, as the quality of borrowers diminishes as the total amount of credit increases. Beyond these constraints that operate at the microeconomic level, the links between money and credit on one hand, activity and inflation on the other, have loosened over time. Taking a long-term view, Schularick and Taylor (2012) distinguish two eras in Finance Capitalism. Pre-WW2, money and credit grow broadly in line with each other and with GDP; post-WW2, money and above all credit grow faster than GDP. 
Furthermore, Kydland and Prescott (1990) denounce a "monetary myth" according to which the money stock, whether measured by the monetary base or by M1 (cash and sight deposits), would lead the cycle and show that this is not the case. Finally, Bussière et al. (2020) show, in the cases of the euro area and the U.S. over the period 1998-2020, that the link between money and inflation has become discernable only in the long run in these two areas.

- The 100\% Reserve approach is static, particularly in the case of SM, which does not take into account that, as money circulates, there is little point in trying to control what it is used for when it is created. In fact, SM should advocate the control of all transactions in order to avoid "unproductive" spending, which of course would be both inquisitive and unrealistic. SM is also static, as it does not consider incentives, for instance when it proposes that reserves are used by the Treasury to distribute lump-sum payments to the citizens ("helicopter money"; Pfister and Valla, 2020). In that regard, one should be mindful that, in presenting the "thought experiment" that was at the origin of the phrase "helicopter money", Friedman (1969) shows that, in the short to medium term, output can rise or fall, due to opposite effects on demand (part of the "helicopter money" is spent) and supply (labour supply is reduced).

- $\quad 100 \%$ Reserve plans support excessive claims. This is particularly the case for LPB and SM. LPB over-emphasizes the capacities of financial markets and fund managers. In that regard, as Chamley et al. (2012) note although their paper supports LPB: "roughly three-quarters of mutual fund managers routinely underperform the market". Conversely, Cochrane (2014) claims: "With today's technology, you could buy a cup of coffee by swiping a card or tapping a cell phone, selling two dollars and fifty cents of an S\&P 500 fund, and crediting the coffee seller's two dollars and fifty cents mortgage-backed security fund". However, this still not the case nowadays. Regarding SM, Jordan (2018) denounces the notion of "debt-free" payments it has recourse to in order to consider money created by Government as an asset as "an illusion". As reminded by Bacchetta (2018), a central bank needs to hold assets to inspire confidence in the currency it issues, whereas only crediting reserves that are created to the Treasury account would create a mismatch in the central bank's balance sheet. Consequently, the losses incurred by the central bank as a counterpart of the reserves created to the benefit of the Treasury would have to be added to the Treasury's debt to get an overall measure of government debt. This would make clear that "redistribution through money creation by the central bank is at best a zero-sum game" (Jordan, 2018) or a "shell game" (Pfister and Valla, 2020). ${ }^{2}$ This would be all the more the case as the central bank and the Treasury have no informational advantage over banks in distributing credit, thus increasing the risk that the loans they grant may turn out to be non-performing.

\subsection{Some undesirable consequences}

Some undesirable consequences of 100\% Reserve plans would warrant adjustments, complements or closer examination. Others cast doubt on the merits of the whole project.

Among the consequences that would warrant adjustments, complements or closer examination are five issues: the availability of safe assets, the loss of liquidity resulting from the reform, its impact

\footnotetext{
${ }^{2}$ Fisher (1936) makes a similar mistake when he envisages that "most of Government debt could be paid almost overnight" as the central bank purchases Government bonds held by banks in order to provide them with the reserves to back sight deposits: he neglects that reserves are a liability of the consolidated Treasury-Central bank balance sheet.
} 
on the cost and availability of loans to SMEs and consumers, a possible increase in the procyclicality of the financial system, and foreign competition.

- Fewer safe assets would be available to collateralize financial market transactions to the extent that short-term Treasuries would be locked in banks' or mutual funds' portfolios to back deposits or mutual funds shares. To remedy this problem, Phillips (1995) proposes three "solutions" which I discuss in turn. The first one would be for the Government to alter the maturity structure of its debt; however, the Treasury would thus increase its funding risk. The second "solution" would be to broaden the class of permissible assets 100\% Reserve banks can hold; however, this would contradict one of the main motivations of the reform. The third "solution" would be for the central bank to pay interest on reserves, as suggested by Friedman (1965), instead of inducing 100\% Reserve banks into purchasing Treasuries. However, as the central bank would itself invest the counterpart of its increased refinancing of banks in Treasuries, it would have to concentrate its purchases on medium and long-term Treasuries. Kay (2009) suggests the Government should borrow more than it needs, but this would also increase its risk-taking. Finally, Cochrane (2014) denies there is a shortage of safe assets with public deficits at the time he writes, and they have in fact increased since then.

- Wallace (1993) has put the argument of the loss of liquidity of the economy forward in the context of 100\% Reserve. Basing his analysis on Diamond and Dybvig model (1983), the author shows that in this model, NB eliminates the role of banking (i.e. the provision of liquidity). Furthermore, Kashyap et al. (2002) show that there is synergy between deposittaking and lending activities, as long as deposit withdrawals and commitment takedowns are not too highly correlated (if the correlation is high, then depositors withdraw their deficits when firms activate loan commitments, triggering a liquidity crisis). In reply, Chamley et al. (2012) and Pennachi (2012) do make the point that trading in securities can substitute for deposits but, as indicated above, this leaves the question of why it has not yet been the case unanswered.

- Along with other commentators, Goodhart (1993) considers the impact of 100\% Reserve on the cost and availability of loans to SMEs and consumers would be detrimental. This is for two reasons. Firstly, banks would lose access to cheap resources, in the form of sight deposits, to funds these loans, an argument previously mentioned by Hart (1935) to express concern about the financial health of banks after the reform (see above). Secondly, moral hazard in the banking system would be reduced by $100 \%$ Reserve. Consequently, the cost of other bank funding sources would increase as banks' shareholders and creditors would bear increased risks (of course, the presumption is that at least part of the extra profit made by banks as a result of moral hazard is already used to cross-subsidize loans). In response to this risk, Cochrane (2014) proposes that the Government subsidizes credit, which could be cumbersome to implement and supposes that the benefits of the reform would at least offset the cost of the subsidy.

- Goodhart (1993) also thinks the reform could increase pro-cyclicality in the financial system, as depositors would withdraw funds from risky banks, in which they would get a better yield in tranquil times, to safe haven 100\% Reserve banks in times of crises.

- Finally, foreign competition might imply that an isolated implementation of the reform would trigger the dislocation of financial activities abroad, thus risking to make the reform counter-productive in terms both of financial stability and of economic activity. However, the remuneration of reserves, that is nowadays current practice in developed economies 
(Drumetz et al., 2015), would limit the loss of competitiveness of the domestic banking sector.

Consequences that cast doubts on the merits of the whole project relate to monetary policy and moral hazard. They are particularly acute in the case of SM.

- Regarding monetary policy, Prescott and Wessel (2016) do not find substantial consequences for NB. However, they present their work, which has recourse to a very stylized model of the economy, as an "exploration". In the case of SM, Jordan (2018) notes the possibility of a conflict between price stability and the provision of a potentially large credit volume. He also underlines that the addition of distributional objectives, implemented through "helicopter money" (see above), would make monetary policy a quasi-fiscal policy. Moreover, directing the allocation of credit would politicize the decision-making process of the central bank (in $\mathrm{B} \& \mathrm{~K}$, the allocation of credit by the Treasury would make it intrinsically political). Overall, monetary policy would risk becoming a compartment of fiscal and industrial policies. More broadly, it is hard to see why and how the central bank could be independent if money is nothing but an attribute of "sovereignty". On a more technical ground, a problem for SM is that, as the policy instrument would be the creation of reserves, this would result in high levels of volatility in money market rates ${ }^{3}$. Additionally, the objective to control both money and credit in SM, and interest rates (i.e. both prices and quantities) in B\&K, could lead to serious market distortions.

- Regarding moral hazard, it would not be eliminated by B\&K or SM, as the Government (in $\mathrm{B} \& \mathrm{~K}$ ) or the central bank (in SM) would play a major role in allocating credit, and would thus be held directly responsible for ensuring financial stability. More generally, in a crisis, even if sight deposits are backed by Government liabilities, the Government would likely rescue financial institutions, whatever their statute, as it has been doing in the past. Indeed, it would do so for the same reasons as nowadays, i.e. to "protect" both savings from losses, although bailouts are eventually paid for by taxpayers and employment by ensuring the continuous provision of credit to firms.

\footnotetext{
${ }^{3}$ Managing a narrow interest rate corridor in order to limit interest rate volatility would make the supply of reserves endogenous, as in the standard monetary policy implementation framework (see Drumetz et al., 2015).
} 


\section{An enhanced topicality}

In spite of the criticisms it has raised, 100\% Reserve could get more topical in the coming years as a result of private sector, central bank, and political initiatives.

\subsection{Private sector initiatives}

Some recent private sector initiatives can be linked to NB.

- In 2016, a former member of the staff of the New York Federal Reserve Bank (NYFRB), James McAndrews, created a bank, The Narrow Bank (TNB), with the purpose of collecting deposits from non-bank financial institutions (central banks, pension funds and mutual funds), and redepositing with the NYFRB. The interest paid by the central bank on TNB's deposits would allow it both to cover its costs and to serve a remuneration slightly higher than the one depositors would get by investing in money market funds. In the summer of 2017, TNB asked for the opening of a so-called "Master Account" with the NYFRB in order to be able to conduct its activities, a procedure that is usually carried out in a matter of days. In August 2018, TNB sued the FRBNY for not responding to its demand. In its response, in March 2019, the FRBNY indicated that the opening of Master Accounts was discretionary (Federal Reserve Bank of New York, 2019). More interestingly, from an economic point of view, it argued inter alia that deposits at institutions such as TNB "could significantly reduce financial stability by providing an unlimited supply of very attractive safe-haven assets during periods of financial market stress". This argument echoes both the one raised by Goodhart (1993) (see above) and one frequently raised against central bank digital currencies (CBDC) (see below). In any case, the legal issue is still unsettled at the time of writing this paper.

- A private sector initiative much more debated in the media is the issuance of stablecoins. Such an issuance could lead to a loss of resources by traditional payment service providers such as banks, especially in developing and emerging economies (Melachrinos and Pfister, 2020), as would be the case with 100\% Reserve. Relatedly, in their second White Paper on Libra, the members of the Libra Association opposed Libra to the fractional reserve system, implicitly delivering the message that Libra, with its reserve invested up 80\% in high-quality short-term Treasuries, would be safer than bank deposits (Libra, 2020).

\subsection{Central bank initiatives}

Some central bank initiatives that can be related to 100\% Reserve have been implemented, some are proposed in the academic literature, and others are considered.

- Although it is not for reasons related to $100 \%$ Reserve, but rather as a by-product of their asset purchases as a monetary policy tool (Drumetz et al., 2015), central banks in most developed economies have created excess liquidity that makes it easier to implement $100 \%$ Reserve. This point was already noted by Fisher (1936) and is echoed in the current circumstances by Dyson et al. (2016). For instance, at the end of June 2020, sight deposits in the euro area stood at 8400 billion and banks held 2500 billion in their current accounts with the Eurosystem plus close to 420 billion in the Eurosystem deposit facility. This means that, at that time, banks could back up around one third of sight deposits with central bank reserves without needing refinancing or reducing the availability of safe assets: the reserves they already held would just have backed 100\% Reserve deposits. 
- In line with SM, although not referring to it, Galí (2020) has proposed "helicopter money" as a money-financed fiscal stimulus.

- In what has been presented as "synthetic CBDC" (Adrian and Mancini-Griffoli, 2019) or "indirect CBDC" (Auer and Böhme, 2020), stablecoins would be backed by central bank reserves. In fact, these stablecoins could as well be dubbed "100\% Reserve stablecoins". More simply, central banks could issue CBDC, as the central bank of Bahamas has already done and the People's Bank of China and the Riksbank among the other central banks more advanced in the project (Pfister, 2020). Libra (2020) also mentions the possibility to replace its single-currency stablecoins with the corresponding $\mathrm{CBDC}^{4}$. In all these instances, whether the unit that is issued is a central bank liability or not, the banking sector would be disintermediated, as in 100\% Reserve, subject to what has been mentioned above about excess liquidity. In addition, as mentioned by Goodhart about the risk of increased pro-cyclicality created by $100 \%$ reserve plans (see above), runs on the banking system would be facilitated, since there would be no need to visit a bank's branch or a cash dispenser anymore in order to convert bank deposits into central bank money. As a countervailing argument, the provision of CBDC as a permanently safe and liquid instrument would better protect the economy in times of crisis (Pfister, 2019, 2020), whereas there would remain a residual risk on stablecoins (Melachrinos and Pfister, 2020).

\subsection{Political initiatives}

In the U.S., several Congress initiatives ${ }^{5}$ have proposed in order to promote banking inclusion and facilitate the distribution of fiscal support to individuals, that they could open accounts either with the Federal Reserve Bank branches or with the U.S. Postal Services branch offices, or even 100\% Reserve accounts with banks. In case they are not be with the Fed, the deposits would be backed by central bank reserves, and thus not covered by deposit insurance; furthermore, they would be "funded by the Federal Reserve". The latter formulation leaves unclear whether the Fed would provide "helicopter money", or else buy assets to provide reserves backing the deposits, or just let the reserves flow from the Treasury's account to the ones of the Post Office or the banks at the Fed or to those of the depositors who would open accounts directly with the Fed. In the first case and in the second case if the Fed has to buy Treasuries to provide the reserves needed to back deposits because it is legally forced to do so, the proposal would be related to SM. In the second case if the Fed acts on its own initiative and in the third case, it could be related to DC, although in DC the opening of accounts backed by central bank reserves is not necessarily linked to the payment of benefits and does not especially aim at the unbanked or underbanked populations.

Whether they originate from the private or the public sector, the above-mentioned initiatives can be linked for most of them to DC or NB and in some cases to SM. In contrast, the original approach (CP) or the more recent LBP have not percolated into recent proposals.

\section{Conclusion}

Addressing the topic of $100 \%$ Reserve is fraught with difficulties of two sorts:

- There is heterogeneity in the approach. Indeed, since the first formulations during the Great Depression, different streams developing or amending the original plan have been

\footnotetext{
${ }^{4}$ Libra plans to issue several single-currency denominations on top of its original basket Libra (Libra, 2020).

${ }^{5}$ See for instance the memorandum of the Committee on Financial Services of the House of Representatives (2020) on "Inclusive Banking During a Pandemic: Using FedAccounts and Digital Tools to Improve Delivery of Stimulus Payments", that itself refers to a similar initiative in the Senate, and Ricks et al. (2020).
} 
put forward, in response to different circumstances or criticisms and with different consequences for the financial system and the economy.

- Most of these formulations lack a well-defined and commonly used analytical framework. This lack of an analytical framework contrasts with more organized schools of thought, such as New Keynesianism, which uses general equilibrium modelling extensively, and with presentations of a final organization, which often go into details, as in descriptions of a Utopia, with Dyson et al. (2016) providing the best example. It also contrasts with strong policy prescriptions, such as the systematic backing of all sight deposits with Government liabilities, in all plans except DC, or the creation of reserves essentially to finance public spending in SM.

In this paper, I present the various 100\% Reserve plans. I show that there are more differences than common features between them. Furthermore, several features make B\&K and SM distinct from other plans whereas LPB appears as a "radicalization" of the CP and NB. DC is original to the extent that it is "à la carte".

I also review the criticisms of $100 \%$ Reserve, discuss them and add our own comments. Some of these criticisms have led to alterations of the original framework, notably with a shift of emphasis from money control, characteristic of the $\mathrm{CP}$, to financial stability and moral hazard considerations, put forward in NB and LBP, whereas B\&K and SM shift the emphasis back to the creation of money.

It appears that:

- The CP and NB would create risks but these risks could probably be managed and accepted if the reform was undertaken on a voluntary basis, as in DC, and not on an imposed and generalized basis, as in the other proposals, also leaving aside the more "hands-on" aspects of DC, that can be separated from 100\% Reserve. In fact, challenges similar to those raised by the 100\% Reserve aspect of DC would arise if a CBDC were issued (Pfister, 2019, 2020).

- LPB remains most likely unrealistic at the current stage.

- SM would create serious risks, notably because of the role played by Government in the allocation of credit, and B\&K could create similar risks.

Overall, the $100 \%$ Reserve reform does not appear as an opportunity to improve the functioning of banking systems. In fact, those systems have already undergone a deep reform following the Great Financial Crisis and have recently demonstrated their resilience to systemic shocks during the Covid-19 crisis. However, SM could easily turn into a calamity. Fortunately, the variant of $100 \%$ Reserve that is becoming topical is rather DC, the one among $100 \%$ Reserve plans least susceptible of upsetting banking intermediation, and it appears as a by-product of other projects, such as the issuance of a CBDC, rather as an end in itself. 


\section{References}

Adrian T., Mancini-Griffoli T. (2019), “The rise of digital money", IMF Note, 19/001, July, https://www.imf.org/en/Publications/fintech-notes/Issues/2019/07/12/The-Rise-of-DigitalMoney-47097.

Allen W.R. (1993), "Irving Fisher and the 100 Percent Reserve Proposal”, Journal of Law and Economics, 36(2), 703-717.

Auer R., Böhme R. (2020), "The technology of retail central bank currency”, BIS Quarterly Review, March, 85-100, https://www.bis.org/publ/qtrpdf/r qt2003j.pdf.

Bacchetta P. (2018), "The sovereign money initiative in Switzerland: an economic assessment", Swiss Journal of Economics and Statistics, 154(3), 1-16.

Benes J. and Kumhof M. (2012), "The Chicago Plan Revisited”, IMF Working Paper, WP/12/202, https://www.imf.org/external/pubs/ft/wp/2012/wp12202.pdf.

Bussière M., Pfister C., Sahuc J.-G. (2020), "Money for nothing? Money, inflation and monetary policy since 2008”, Banque de France Bulletin, forthcoming.

Chamley C., Kotlikoff L. J., Polemarchakis H. (2012), "Limited Purpose Banking - Moving from “Trust Me" to "Show Me" Banking", American Economic Review: Papers and Proceedings, 102(3), 113119.

Cochrane (2014), "Toward a Run-Free Financial System", in M. N. Baily and J. B. Taylor (ed.), Across the Great Divide: New Perspectives on the Financial Crisis, Chapter 10, Hoover Institution, Stanford University, https://ideas.repec.org/h/hoo/bookch/8-10.html.

Committee on Financial Services of the House of Representatives (2020), Memorandum on "Inclusive Banking During a Pandemic: Using FedAccounts and Digital Tools to Improve Delivery of Stimulus Payments", https://www.congress.gov/116/meeting/house/110778/documents/HHRG-116-BA0020200611-SD002.pdf.

Diamond D., Dybvig P. (1983), "Bank runs, deposit insurance, and liquidity", Journal of Political Economy, 91(3), 401-419.

Dow S., Johnsen G., Montagnoli A. (2015), “A critique of full reserve banking”, University of Sheffield, Economic Research Paper Series, $N^{\circ}$ 2015008, https://www.sheffield.ac.uk/polopoly fs/1.448817\%21/file/paper 2015008.pdf.

Drumetz F., Pfister C., Sahuc J.-G. (2015), Politique monétaire, second edition, De Boeck.

Dyson B., Hogdson G., van Lerven F. (2016), Sovereign Money - An Introduction, https://positivemoney.org/wp-content/uploads/2016/12/SovereignMoney-AnIntroduction20161214.pdf.

Federal Reserve Bank of New York (2019), Memorandum of Law in Support of Defendant Federal Reserve Bank of New York's Motion to Dismiss, Case 1:18-cv-07978-ALC, Document 21, https://www.tnbusa.com/wp-content/uploads/2019/03/2019.03.08-HNC-Motion-to-DismissBrief.pdf.

Fisher I. (1936), "100\% money and the public debt", Economic Forum, April/June, 406-420, http://realmoneyecon.org/lev2/images/pdfs/100percent money.pdf. 
Friedman M. (1965), A program for monetary stability,

https://miltonfriedman.hoover.org/friedman images/Collections/2016c21/Houghton 1965.pd f.

Friedman M. (1969), The Optimum Quantity of Money and Other Essays, Macmillan.

Galí J. (2020), “The effects of a money-financed fiscal stimulus”, Journal of Monetary Economics, 115, November, 1-19.

Goodhart C. (1993), "Can we improve the structure of financial systems?”, European Economic Review, 37, 269-291.

Gorton G. (2009), "Information, liquidity, and the (ongoing) panic of 2007”, American Economic review: Papers and Proceedings, 99(2), 567-572.

Hart A. G. (1935), "A Proposal for Making Monetary Management Effective in the United States", Review of Economic Studies, 2(2), 104-116.

Jackson A., Dyson B. (2012), Modernizing Money: Why our Monetary System is Broken and How it Can be Fixed, London, Positive Money.

Jordan (2018), "Why sovereign money would hurt Switzerland", Swiss National Bank, https://www.snb.ch/en/mmr/speeches/id/ref 20180503 tjn.

Kashyap A., Rajan R., Stein J. (2002), "Banks as liquidity providers: an explanation for the coexistence of lending and deposit-taking", Journal of Finance, 57(1), 33-73.

Kay J. (2009), Narrow Banking: The Reform of Banking Regulation, CSFI report, https://www.johnkay.com/wp-content/uploads/2009/12/JK-Narrow-Banking.pdf.

Keynes J. M. (1923), A Tract on Monetary Reform.

Knapp G. F. (1905), The State Theory of Money.

Knight F., Cox G., Director A., Douglas P., Hart A., Mints L., Schultz H., Simons H. (1933), Memorandum on Banking Reform, Franklin D. Roosevelt Presidential Library, President's Personal Fila 431.

Kotlikoff L. (2010), Jimmy Stewart is Dead: Ending the World's Ongoing Financial Plague with Limited Purpose Banking, Hoboken, NJ, John Wiley \& Sons.

Kydland F.E., Prescott E. C. (1990), “Business Cycles: real Facts and a Monetary Myth”, Federal Reserve Bank of Minneapolis, Quarterly Review, 14(2), 3-18, file:///C:/Users/E086254/Downloads/qr1421\%20(4).pdf.

Lainà P. (2015), "Proposals for Full-Reserve Banking: A Historical Survey from David Ricardo to Martin Wolf”, Economic Thought, 4(2), 1-19,

Libra (2020), White Paper v2.0, https://libra.org/en-US/white-paper/?noredirect=en-US\#coverletter.

Litan R. (1987), What Should banks Do?, Washington, DC, Brookings Institution.

Lucas R. E. (1976), "Econometric Policy Evaluation: A Critique”, Carnegie-Rochester Conference Series on Public Policy, 1, 19-46. 
Melachrinos A., Pfister C. (2020), "Stablecoins: A Brave New World?", Journal of Blockechain Law and Policy, forthcoming.

Pennachi G. (2012), “Narrow banking”, Annual Review of Financial Economics, 4(1), 141-159.

Pfister C. (2019), “Central Bank Digital Currency: One, Two or None?”, Banque de France, Working Paper, 732, https://publications.banque-france.fr/en/central-bank-digital-currency-onetwo-or-none.

Pfister C. (2020), Central Bank Digital Currency, Banque de France, https://publications.banquefrance.fr/en/central-bank-digital-currency.

Pfister C., Valla N. (2020), "Helicopter money: Panacea, shell game or Faustian pact?”, 2020, Views - The EUROFI Magazine, April, 46, Eurofi Magazine 2020-Valla-Pfister-Helicopter moneyPanacea, shell game or Faustian pact.

Phillips R. J. (1995), "Narrow Banking Reconsidered", Levy Institute, Policy Brief, 18, http://www.levyinstitute.org/pubs/ppb17.pdf.

Prescott E. C., Wessel R. (2016), "Monetary Policy with 100 Percent Reserve Banking: An Exploration”, NBER Working Paper, 22431, https://www.nber.org/papers/w22431.pdf.

Ricks M., Crawford J., Menand L. (2020), “FedAccounts: Digital Dollars”, George Washington Law Review, forthcoming.

Schularick M., Taylor A. M. (2012), "Credit Booms Gone Bust: Monetary Policy, Leverage Cycles, and Financial Crises, 1870-2008”, American Economic Review, 102(2), 1029-1061,.

Soddy F. (1926), Wealth, Virtual Wealth and Debt: The Solution of the Economic Paradox, London, George Allen \& Unwin.

Tobin J. (1963), "Commercial Banks as Creators of "Money"”, Cowles Foundation Discussion Paper, 159, http://cowles.yale.edu/sites/default/files/files/pub/d01/d0159.pdf.

Tobin J., (1978), “A Proposal for International Monetary Reform”, Eastern Economic Journal, 4 (34), 153-159.

Tobin J. (1985), "Financial Innovation and Regulation in Perspective", Bank of Japan Monetary and Economic Studies, 3(2), 19-29, https://www.imes.boj.or.jp/english/publication/mes/1985/me3-23.pdf.

Tobin J. (1987), “The case for Preserving Regulatory Distinctions”, in Proceedings - Economic Policy Symposium - Jackson Hole, Federal Reserve Bank of Kansas City, 167-183, https://www.kansascityfed.org/publicat/sympos/1987/s87tobin.pdf.

Wallace N. (1996), "Narrow Banking Meets the Diamond-Dybvig Model”, Federal Reserve Bank of Minneapolis, Quarterly Review, Winter, 3-13, file:///C:/Users/E086254/Downloads/qr2011.pdf. 